$\mathbb{T}$ periodica polytechnica

\author{
Architecture \\ $39 / 2(2008) 49 \sqrt{58}$ \\ doi: 10.3311/pp.ar.2008-2.02 \\ web: http://www.pp.bme.hu/ar \\ (c) Periodica Polytechnica 2008 \\ RESEARCH ARTICLE \\ Katalin Marótzy \\ Received 2008-01-25
}

\section{The Erdődy Castle in Vörösvár}

\begin{abstract}
The township of Rotenturm an der Pinka-ci-devant Vörösvár - lies along the Pinka in Burgenland, just 20 kilometres from Szombathely. In the middle of the village, in a deserted park stands an especially beautiful architectural creature of the Hungarian Romanticism, the Erdödy Castle as a masterpiece of Antal Wéber.
\end{abstract}

The building is historicising by mixing the styles from some architectural elements like the column of the carriage passage shown above to the composition itself. However, the building is basically differentiated from the style-mixing historicism of the close of the $19^{\text {th }}$ century by the fact that every architectural unit is still part of a suite with the traditional formal logic, with traditional proportions.

\section{Keywords}

architecture-history $\cdot$ romanticism $\cdot$ historism $\cdot$ castle

\section{Katalin Marótzy}

Department of History of Architecture and of Monuments, BME, H-1111 Budapest Múegyetem rkp. 3., Hungary

e-mail: mkata@et.bme.hu

\section{History of construction $3,6-8$}

The first written record of the location is from 1355, when the township is mentioned as "Veresuarfelde". In the $13-14^{\text {th }}$ centuries defending the road leading from Pinkafo" to Szombathely, in the northern corner of the present day castle park stood a water castle surrounded by the artificial and main branches of the Pinka. In 1424 the place was licensed for holding markets by King Sigismund. In that year its first well-known landlord, István Vörösvári pledged "Castrum Wereswar" to Bertold von Ellerbach, who had the ramshackle castle rebuilt. Under the ownership of his successor, Bertold von Ellerbach II, the castle is first mentioned by its German name, Rotenturm.

At the end of the 15 th century, after frequently changing owners, the Zrínyis and the Széchenyis had possession of the castle - Tamás Bakócz purchased the "Castellum Weresvar" and the rights to hold markets from the Ellerbachs. In 1532 the fortress passed to Péter Bakócz, cousin of the Archbishop of Esztergom, who took the name Erdődy Monyorókeréki after his birthplace. Thenceforward to 1929, with the exception of half a century the castle had been in the possession of the family. Péter Bakócz battled with the Stubenbergers, whose armies set fire to the castle in 1540, which suffered heavy damage as a result.

In the $17^{\text {th }}$ century Sándor Erdôdy II created a park around the castle, then his grandson, László Erdôdy built the "old castle" - to which the deer-park pertained too - on the base of the former moated castle and put up a guesthouse in the territory of the village. The first military survey also provides evidence of this construction stage. [1 The "old castle" was a building with four corner towers, locking in the square courtyard, and encompassed by the mediaeval works, ramparts, artificial and natural moats. In the house No. 82 of the village a sandstone block used as stairs was found, the inscription of which, MCEC/RMCC/MDCLXXXXVI, may represent the commencement of the construction of the "old castle".

At the beginning of the $19^{\text {th }}$ century György Erdődy II had the stronghold that was already decaying by that time, pulled down, then between 1820 and 1825 he had a castle built on the western side of the territory [1]. Toward 1840 he tailored the Baroque

${ }^{1}$ Col. II. Sec. VI. (1782-85) 


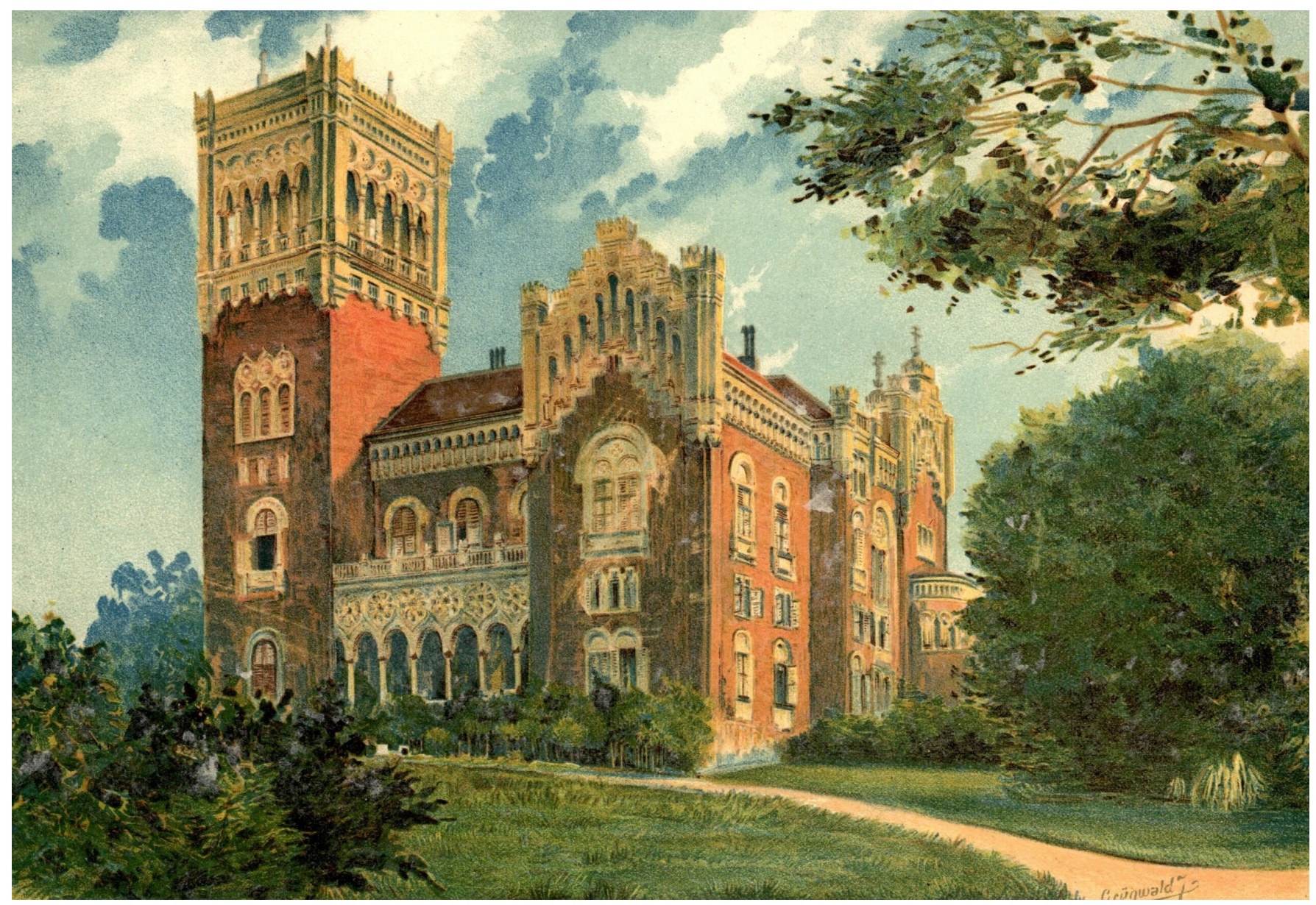

Fig. 1. The Erdődy Castle in Vörösvár [13]

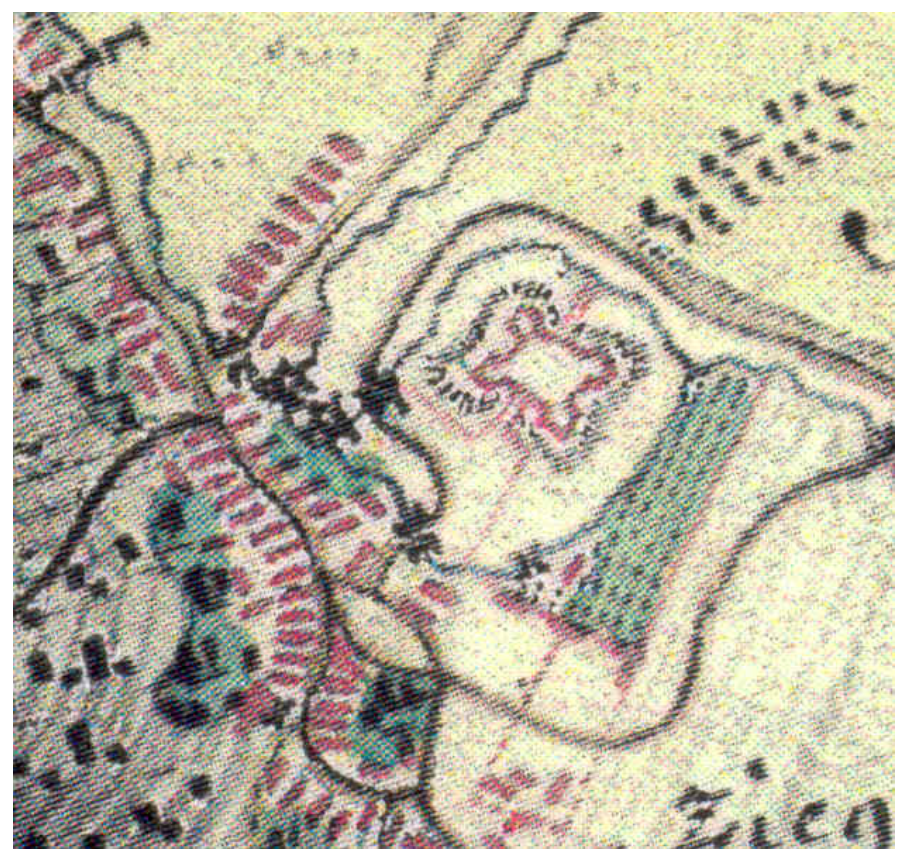

Fig. 2. A detail from the first military survey

park to a landscaped garden. The transformation is traceable on the maps of the second military survey. On the sheet of the second survey covering the whole country there are still pathways of a square layout in the park, whereas on the more expansive supplement made some years later a more loose arrangement of pathways can be seen. Through the transformation of the park the northern corner, which earlier sharply reminded us of the moated castle, became an integral part of the whole garden.

The construction of the baronial residence was carried on by Count István Erdődy. During his first marriage he had a second storey built onto the castle - maybe because of the birth of his many children.

The mansion had two storeys, in its ichnographical system a passageway was created at the entrance because of the increased height; this led to the staircase, which was added to the building from outside. The service-stairs in the southern corner were also built as external addition. On the supplement of the second military survey the salient bulk of the stairs is distinctly visible, based on this we may take the rebuilding between 1835 and 1844. In its functional role, the kitchen may have been in the northern corner. This is indicated by the ground-plan on which there is a room across the whole width of the building with a chimney in the middle.

A set of apartments were located upstairs in the southern section and, the bulky chimney group of the "central heating", which can be approached from the service-stairs, is distinctly visible on the survey made in the 1970s. We can conclude the frontal design from a detail of a newspaper article illustration from the beginning of the $20^{\text {th }}$ century; simple string-framed

\footnotetext{
${ }^{1}$ Col. XX. Sec. 53. (1828-44)
} 


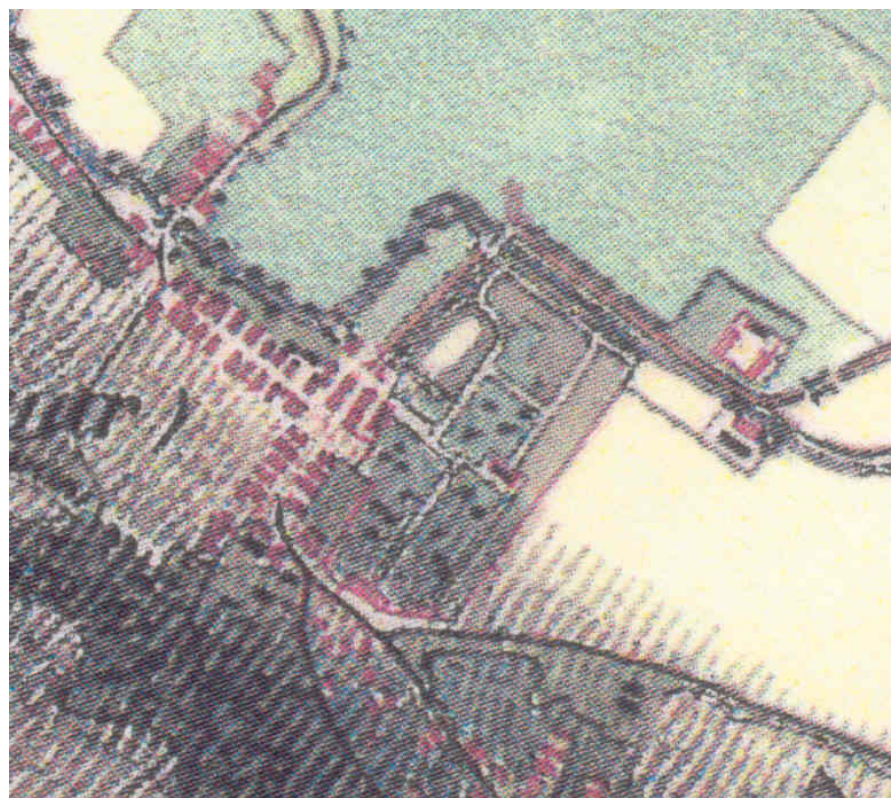

Fig. 3. Detail from the second military survey

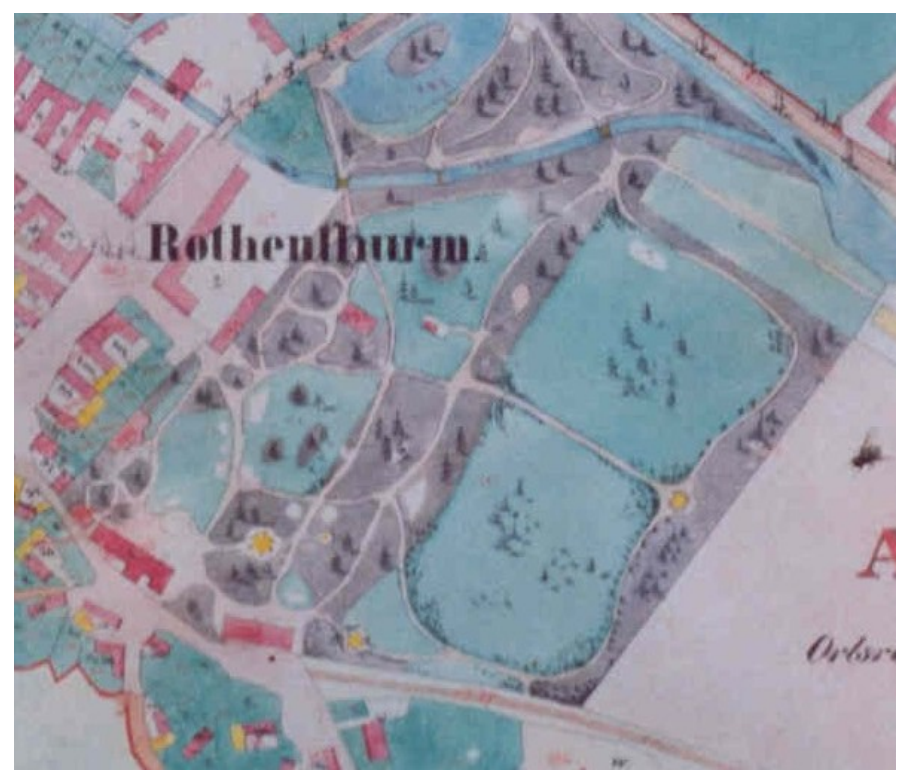

Fig. 4. Detail from the supplement of the second military survey Die Umgebungen von Wien und Baden. (1844)

openings form a line on the smooth-surfaced wall. The Romantic form of the attic of the cornice in the picture may be original but conceivably it may be connected to the construction of the "new castle" along with the carriage passage.

Presumably, the enlarged mansion did not suit the aristocrat, who asked Miklós Ybl in 1857 to design the new castle ${ }^{2}$ In the end this charge was laid to Antal Wéber 3 the new castle was built and the park enlarged, the "old castle" was later used as guesthouse. "The castle, true to its name, made of redbrick, in rich Roman style, rising on the side of the hill was built based on

\footnotetext{
${ }^{1}$ Szalon Újság. 1901, January 10. pp. 6.

${ }^{1}$ SCHMELLER-KITT 1974. fig. 474.

2 SCHMELLER-KITT 1974. pp. 423.

${ }^{3}$ Life and works: YBL 1958.
}

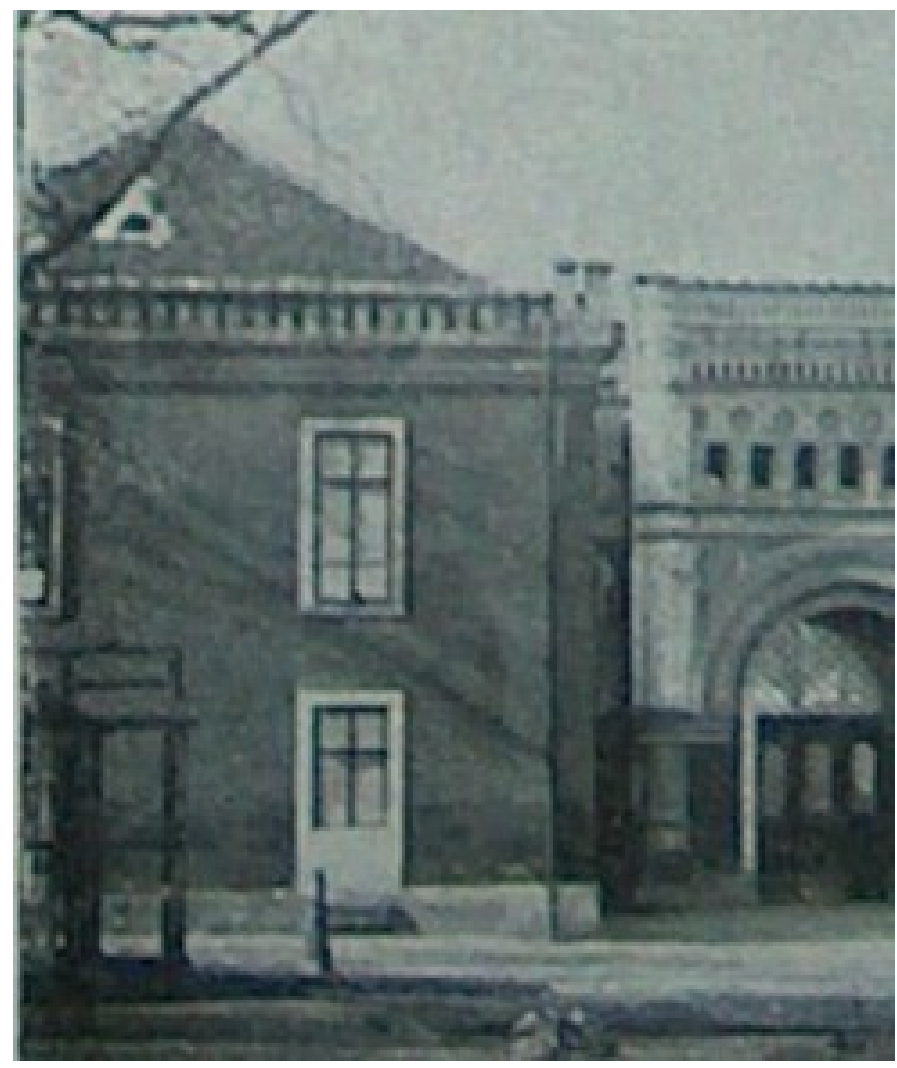

Fig. 5. Details of the south-east front of the mansion ${ }^{1}$

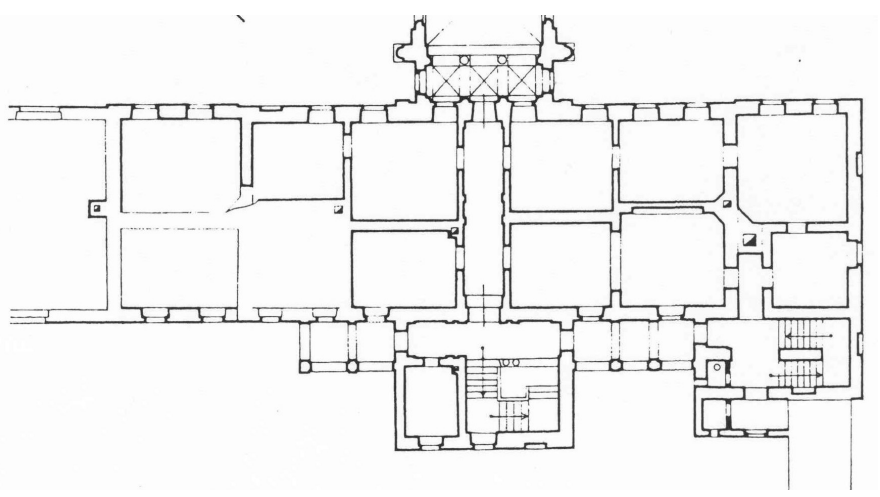

Fig. 6. The survey of the mansion (1970)[7]

the plans of and under the control of Wéber, the well known architect from Pest, and was erected almost solely by local craftsmen. The Count had the names of all of them engraved on a copperplate, which was fixed on a wall in the chapel and on which it is also mentioned that the village of Vörösvár gave the lime needed for the construction without charge." 4

At the beginning of the $20^{\text {th }}$ century the Castle was the Erdődys' preferred residence, Count Gyula Erdődy and his family lived here, with his son, Lajos succeeding to the estate in 1917. By that time the landscaped garden encompassed the castle with spreading trees. According to the evidence of contemporary photographs, [2] pyramid boxwoods grew close by the building, in front of the north-eastern loggia and the southeastern balcony, the plants "give a nice view of many spots of

${ }^{4}$ PULSZKY 1877. pp. 731. 
the surrounding rolling valleys, backed by the light blue Styrian snow-caps on the horizon".

The decay of the building began in 1924 with a fire, in which the famous archives were destroyed and the roof burnt down. In 1929 Miklós Széchenyi, the heir on the female side needed to sell his estate because of his debts to Jan Kubelik, the famous Czech violin virtuoso. In 1928 the building was taken under Monument Protection, the remaining goods and chattels were auctioned. After the Budapest Hermes Bank, the Province of Burgenland became the owner. The condition of the castle worsened, the old wing was torn down between 1961 and 1972, the park ran wild and only essential preservation works were carried out: the roof and the eaves were mended, the side of the carriage passage was shouldered with a concrete wall faced with bricks, the openings were walled in and the whole territory was fenced.

In the end an Arab Sheik, Assad Saad will likely purchase the estate and three quarters of its landscaped garden for 85 thousand Euros (approximately 21.5 million HUF) with the purpose of using it as a summer residence. However, according to the contract he shall spend over the next ten years 22 million Euros (approximately 5.5 billion HUF), which is the pre-estimated amount of the renovation required for the estate. A helipad, a house of prayer and a deep garage are also planned. Unfortunately, the park, which has been open to the public so far, will become a private area.

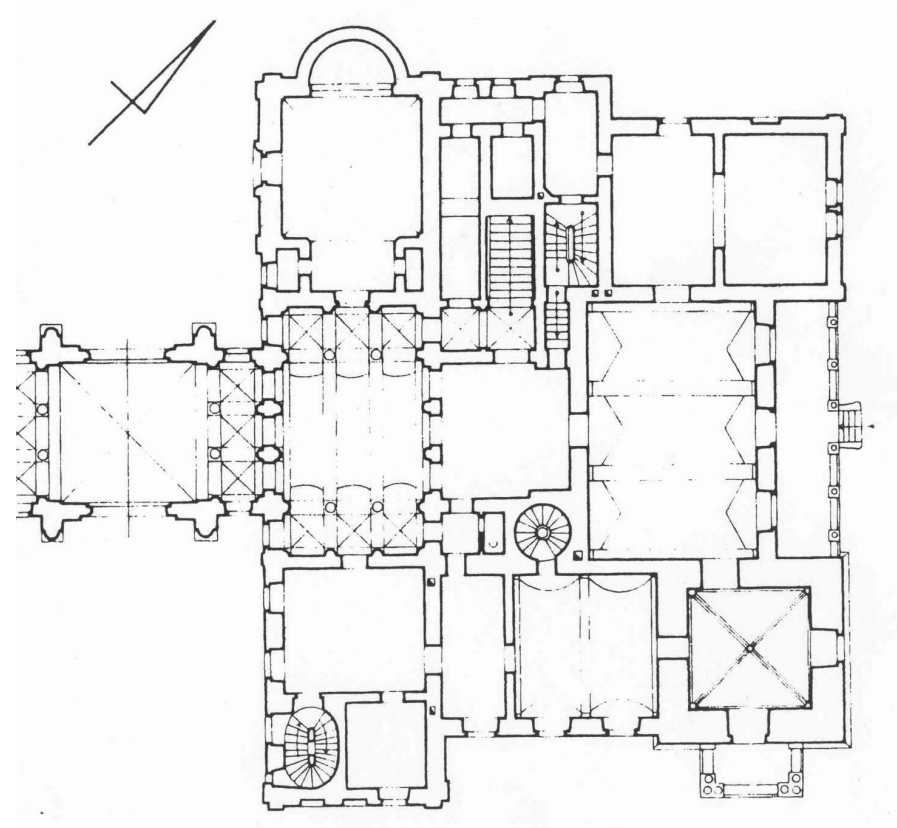

Fig. 7. The plan of the Castle (ichnography from the 1970s)

\section{Interiors}

The still standing "new castle" in a Romantic style joined with a carriage passage to the old wing, from here a range of interiors opened which included the representative rooms leading axially in a north-eastern direction. The larger space of the

\footnotetext{
${ }^{4}$ SCHMELLER-KITT 1974. fig. 474.
}

cross-vaulted carriage passage was attached to the two wings of rooms by a section of lower height that was covered by threethree cross-arched vaults resting on pillars and heightened by stairs. The form of the capitals of the pillars supporting the vault is late Gothic, the ornamentation recalls early Romanesque forms. However, this space is not medieval at all, its clear forms connect it rather to the Renaissance.

The range of representative interiors of the "new castle" started with a richly detailed Romantic vestibule, which was galleried on two of its sides. The middle part of the vaulting of the vestibule comprised a range of square vaults, which were framed on a very narrow rectangular plan between the architraves; the vaults under the gallery, between the equally spaced architraves are like the mediaeval Gothic lierne vaults, the ribs are rather symbolic though, they are only reeds with a small cross-section, peculiarly to Romanticism. The pillars of the gallery are held by columns with capitals similar to those of the carriage passage, the upper level is linked visually with the vestibule by circular headed coupled windows sitting on an embattlement. On proceeding to the middle of the representative interiors there is the space of the hall, presumably of a lower inner height, we then come to the large arched salon. The interior of the latter has become dilapidated by this time, but taking the spring-bases into account it can be assumed that it was ornamented with the form details similar to those of the vestibule. From here one could step out to the slightly narrow balcony, which gave a spectacular view of the park. This direction was the other one from where the representative interiors revealed themselves, the footpath from the village across the park also led to here.

The chapel opened from the left of the vestibule, which had a chancel and used to be ornamented with frescos by Károly Lotz, by this time whitewashed. On the straight mensa there stood a simple, gold and white tabernacle, introflexed in the middle. The Carrara marble statute of the chapel, named "Maria with the child", the legend of which is C. Steinhauser f. Roma 1857, can be found in the parish-church today.

From the lobby to the right the "gentlemen's room", the men's set of apartments must have opened, which had a lower inner height compared to that of the range of the representative interiors. From here and from the hall one could get to the vaulted anteroom of the library in the bottom of the castle tower. Between the hall and the anteroom of the library a little retiring room was wedged in. Looking from the tower the dining room was on the opposite side of the large salon, it was served from the kitchen in the cellar through a particular staircase and a server. On the ground-plan there are markedly a lot of staircases, these enabled the serving of the inhabitants and the guests comfortably on the one hand and ensured an access to the mezzanine on the other. As the order of the frontal openings shows, this mezzanine used to serve as the chancel of the chapel, the gallery of the vestibule and was above the men's set of apartments and the dining room.

On the opposite side of the hall an ornamented staircase led to the first floor. From its medial landing a narrow door led to the 


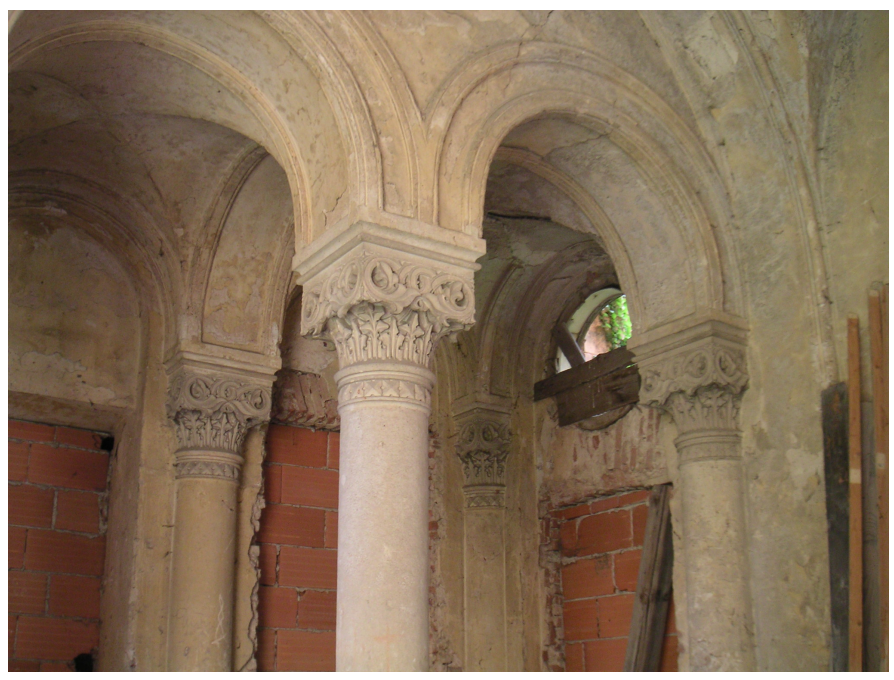

Fig. 8. The areas adjacent to the carriage passage

mezzanine between the ground floor and the first floor, having a lower inner height and containing mainly serving rooms. On the first floor the billiard room was above the large salon, from here one could step out onto the balcony. It was on the first floor of the tower where the rightly famous archives were, which their thick vault and their iron door to defend against fire, unfortunately to no avail, as in 1924 the whole collection was destroyed by flames. An anteroom, named today as the search-room must have adjoined the archives in a similar way to that of the library.

The interiors were ornamented in a Romantic style, in harmony with the exteriors, in the halls Bronze Age chisels, Roman dishes and figurines, Hungarian, Turkish and Italian weapons, the childhood portrait of Ferenc Rákóczi, a life-sized painting of Miklós Zrínyi and a mounted lion evinced the owner's interest in history and passion for hunting. The lunettes in the lunchroom, library and gentlemen's room of the ground floor were made by Károly Lotz. Antal Wéber, the designer of the building's brother-in-law reflected the interest of the owner in respect of their subject. 5

A part of the later furnishings were planned by Count Gyula Erdődy and at that time his amateur painter wife, Emília Széchenyi's aquarelles must have also adorned the walls. 6

The rich interior ornamentation fits the tendencies of the period. As Anna Zádor developed, 7 it is striking that in the burgess houses of a high standard and in the noble castles the expensive interior decorations had already appeared in the period before the Compromise, after the severe interiors of the Classicism.

\section{Facades and body of the castle}

The exterior forming the castle is rich and imaginative, similarly to the interiors'. The body, the ground-plan of which is almost square, is made more exciting by the various, gabled

\footnotetext{
${ }^{5}$ YBL 1938. pp. 83-85.

${ }^{6}$ BOROVSZKY 1898. pp. 116

${ }^{7}$ ZÁDOR 1981. pp. 22.
}

bays, the apse of the chapel and the tower dominating the whole building. The detail forms evoke a lot of former styles but some motif returns on the facades connect the building through their uniform profiling.

The facades are rendered, brick-red coloured, with bonds spaced further apart rather than imitating the divisions of bricks. It is an interesting historical game that the colour of the facades accords with the name of the village, which refers to the fairfaced brick-facades of the mediaeval castle. The castle has again become, because of its brick-red colour, the symbol of the village.

Some of the architectoni Carrara details are lighter, plastered with a greyish yellow render, made of a light sandstone on the places which are more exposed to weather and which are stressed statically. In the present condition of the building the two sorts of ornamentation stand out in sharp contrast from each other, because the sandstone having passed the test of time, its colour is lighter, its profiles are sharper. Of course the exterior had been organic at the time of the construction.

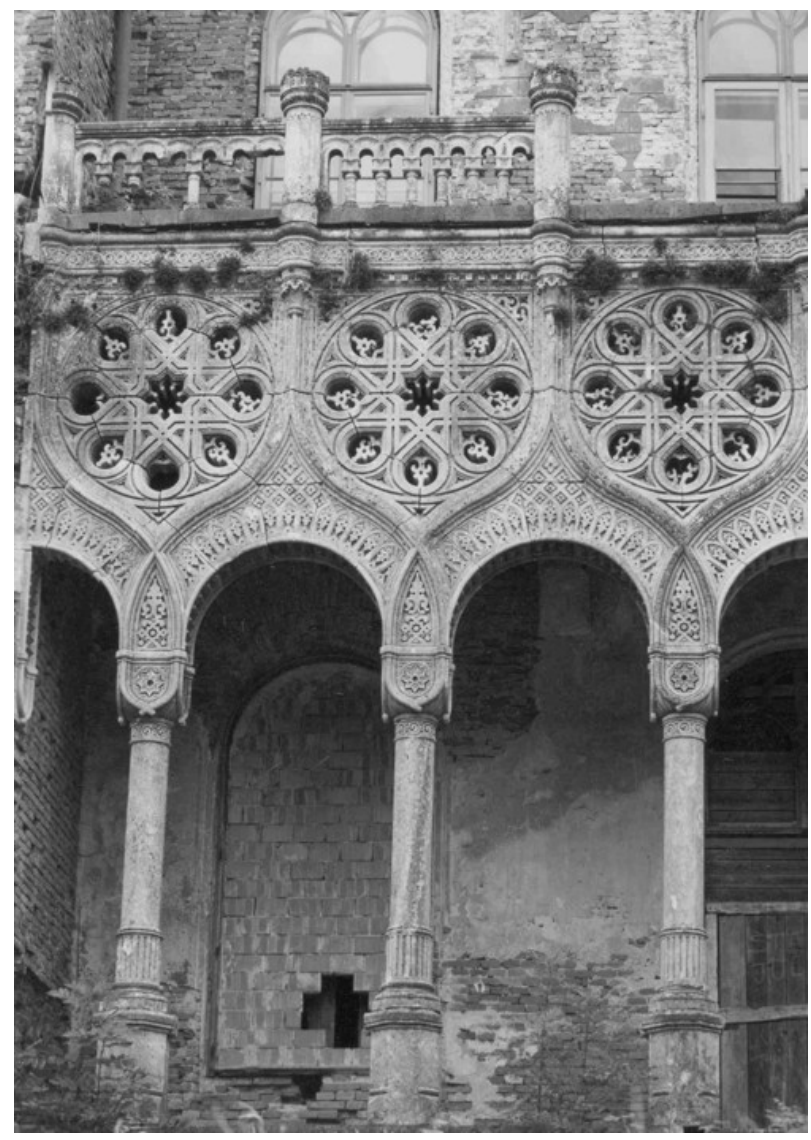

Fig. 9. Balcony

\subsection{The tower and the north-eastern face}

The north-eastern face of the castle, which we can take as the main front, splits to three parts, its sharpest element is the fourstorey tower on the left side of the castle. The gabled bay on the right hand side is of the same width, the section divided into three axes between the other two is made airier by the loggia on the ground floor. 
On the ground floor of the tower the circular headed window joins to the scarcement by a window skirt plastered with grey render. The frame of this window had two mouldings, at the arch it used to have a richer pattern as can be concluded from the impression on the render. Pillars corbelling on consoles frame the skirt of the first-floor window, it is ornamented with a geometric pattern based on an eight-pointed star. The division of the joiner-structured casement evokes the Florentine early Renaissance palaces. Between the window of the first floor and that of the second floor there are three tiny blind openings at the same height as the miniature gallery of the set-back middle section, these are circular headed, leaning on a simple sill, the moulding of the frame are doubled at the arch. Inside the blind openings there is a geometric ornamentation in two circles under one another, in quite a ruined condition. The three circular headed windows of the second floor, framed with mouldings, are sitting on a common sill, their ornamentation is three trellised round openings taking place axially above them. These openings are held together by a frame of double mouldings, slightly out of the primer mouldings, ending in an apex above the arches.

All around on the top of the tower there is a jetty gallery, which is framed at the corners with battlemented pillars, whereas the bottom of the gallery starts with an arcature jointed with floating buttresses and a dentil cornice. The encompassing corridor is wrapped around by a range of cubic headed arcades, above the spans there are circular openings with stone tracery, framed with double mouldings. The loggia is covered with a crowned pillar of arcature.

The tower is formally the most outstanding element of the building dominating the castle with its massive body. The library and the famous archives were in this part of the building, which most reflected the owner's field of interest. Formally the tower is a relative of the tower of the castle of Galánta, which was reconstructed also based on Antal Wéber's plans, nevertheless it looks thicker and more massive because of the extent of its body. The pair of towers of the Roman Catholic Church in Fót is also similar in respect of the upper arcades, but the frontal composition is completely different.

Below the set-back central part of the north-eastern front there is an arcaded loggia, above that there is a balcony. The forms of the ground floor loggia reflect very strong Moorish influence, the structure of arched columns is made more oriental by the pierced, circular ornaments and the ogee arches above the circular arches in addition to the Islamic pattern. The balcony could be reached via a stone staircase; the middle axis is not dominant. Between the cubic headed columns standing on footings there was originally a stone railing. Above the ornate stone trellis it is still possible to see what the ground-floor railing was like. The loggia is designed of arches, what is shown by the members running from the two sides of the capitals to the first floor. The two circular headed windows and the door of the big salon opened behind the arcades, each of them is framed around like ribbons. Their joint-structure cannot be seen because of the walling up, but based on the size of the windows we can assume that they have been constructed similarly to the first-floor windows. The first-floor windows of the middle section are formed identically with the first-floor windows of the tower, the pillars are held by a miniature gallery having circular headed arches and even smaller horseshoe arches between them.

The body of the right hand side of the front juts out to the same extent as the tower but it looks much thicker on account of its gabled form and that it is rimmed by a vertical wall banding. On its ground floor there are two straight headed windows close to each other, they are held together by a semicircular arched framing. The openings of the mezzanine are narrow, almost loophole-like windows formed as a hood moulding, sitting on a common sill. The first-floor window is a developed form of the other windows of the floors of the front, with the difference that in this case not the joint-structure but the framing of the rendering evokes the Florentine early Renaissance palaces. In respect of its detail forms this window can definitely be connected to the Rundbogen style, there are geometric patterns designed of circular arcs in the strips taking shape by the moulding framing. The gable is closed by a stepped miniature gallery, with a design similar to those of the tower. The miniature gallery starts with a soft arcature shaped from the rendering; the cubic-headed columns are sitting on stone consoles. Above the arches there are foiled patterns, hardly visible by today; the gable is closed by a battlement ornamented with a range of ogee arches.

The Moorish-like, recessed middle (frontal) part between the two closed bodies refers unequivocally to the Florentine palaces. In this way, if we look not only at the details but the composition itself, the oriental elements show up on the north-eastern face through a double quotation. The closed - recessed - closed composition appears later with mellower rates and classic details forms on Antal Wéber's Adam Palace, maybe the most famous building of his.

This is the face, on which the most technological curiosities of the construction of the castle can be observed. The railings of the ruined balcony allow us to see how the stone elements of the railing had been fitted and constructed. The depressed nests on the floor and the groove on the side of the footing served for this. Climbing onto the balcony, the supporting structure can also be observed with riveted iron beams visible in a longitudinal- and cross-girder system.

\subsection{The north-western face}

Walking around the building the poorest view opens from the north-western face, this may have been the same at the time of the construction, as the width of the park is the smallest in this direction. The front keeps jutting out southward in two brick tiers as the functions change behind the face.

On its left side, which is the front of the ground-floor dining room and the first-floor smaller salon, the design follows the bay of the right side of the main front, the framing of the openings are the same, with the difference that in the height of mezzanine 


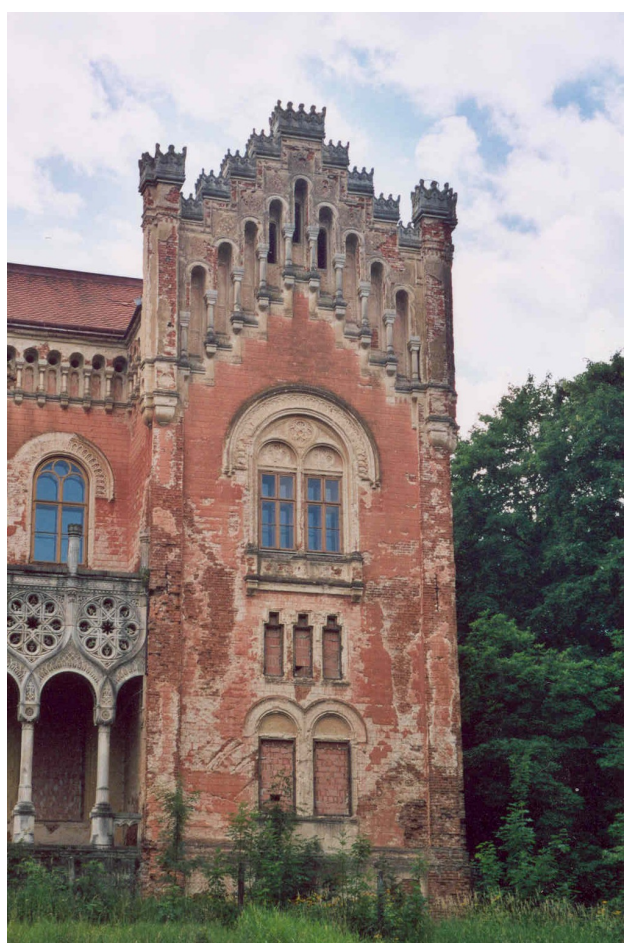

Fig. 10. Detail of the north-western front

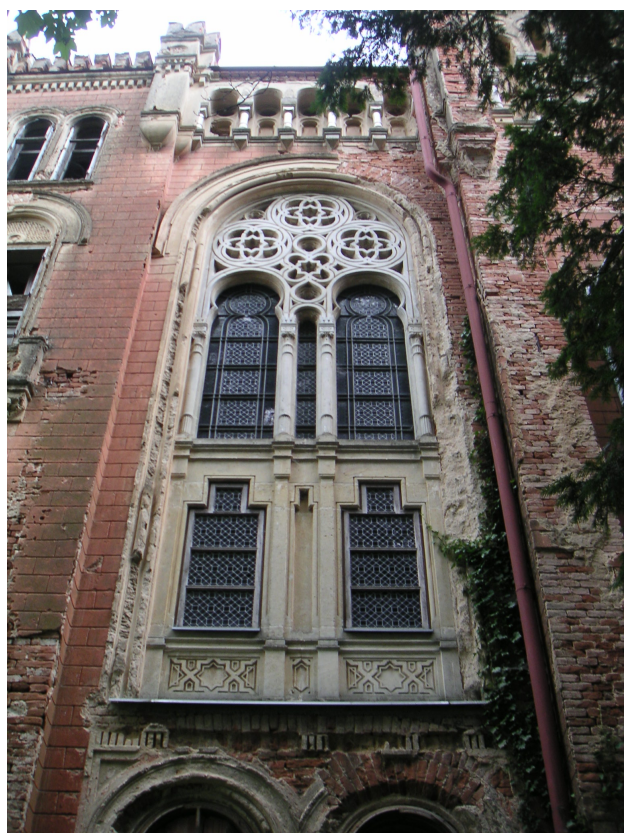

Fig. 11. Detail of the chapel

there are windows with two hood-mouldings instead of three. This part of the front is divided into two axes, on its left side a floating buttress that frames the gable of the main front juts out, the offset is held by a miniature gallery.

The middle part of the front revets the body of the main and the by-staircase. The forming of the by-staircase is similar to the aforementioned, above the first-floor it is improved with another level of moulding-framed coupled windows. Because of this opening, which results from the function, the cornice is not as high on this section, it has dentil decoration and is framed by floating buttresses from two sides. In case of the main staircase the miniature galleried cornice returns and on this part the openings of the three storeys - namely the ground floor, mezzanine and first floor - are given an organic framing. Above the two circular-headed windows of the ground floor a little dentil pillar provides the sill for the coupled window with hood moulding, which joins the landing of the staircase. Between the two windows little pillars run further up to the first floor encompassing a blind opening with hood moulding. In the window-skirt there is a geometric ornamentation shaped by constructing rotated squares together, which evokes expressly the Gothic traceries. At the height of the first floor there are horseshoe arched windows of the same system as the one below the first floor, the arches are held by responds of leaf-bud capital. Above the windows there is a stone trellis consisting of three bigger and four smaller circles, constructed by arches. The range of openings, which becomes ornamentation, is framed by two forceful mouldings extending the floors, the framing of the semicircular arcs taking shape above is similar to that of the floor windows previously mentioned. Today this special detail formed of stone sticks sharply out of the dilapidated wall-surface; it could have made the main staircase very representative with its lead-glass casements in former times.

From the north-western face the blind semicircular apse of the chapel juts out strongly, this is framed by antae on both sides. In respect of the composition it is a formal version of the bay on the highest level and the right side of the main face. On the apse there are five circular headed, moulding-framed blind openings, with an ornamental-like geometric pattern inside. Outside the mouldings, in the plane of the rendering a secondary frame different from the aforementioned ones is visible; it runs as a simple ribbon from below, then the frame imitates a cushion and at the end it is closed by three mouldings. The design of the inner wall-surface of the arcature crowning the apse of the chapel is also similar to the ornamentation of the blind openings.

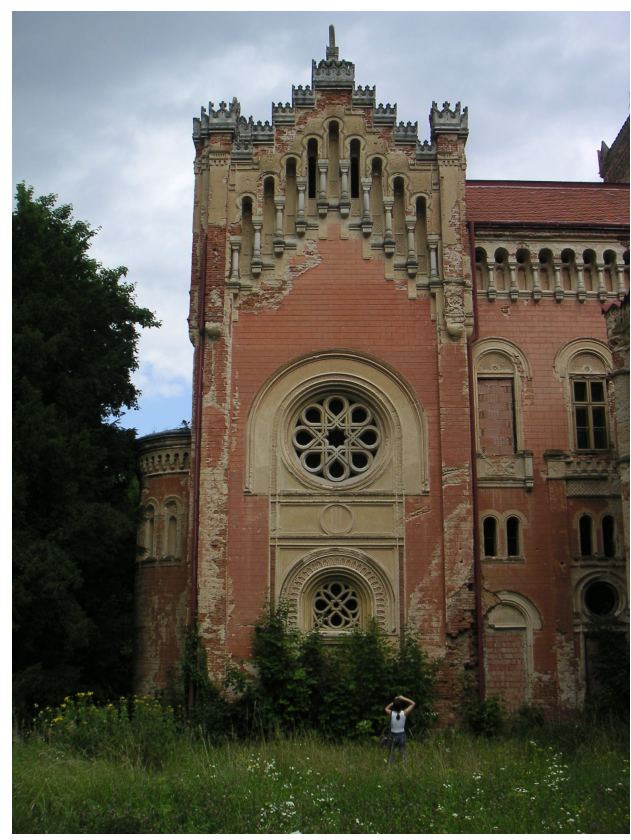

Fig. 12. Detail of the side elevation of the chapel 


\subsection{The south-western front and the carriage passage}

From the Schulgasse a good view opens from the southwestern face of the castle, but at the time of the construction the former two-storey side wing blocked the full view. Because of this the composition is divided to three articulated parts. On the left side the side elevation of the chapel is determinant, this is divided from the frontal part of the right side by the salient body of the carriage passage. The aisle of the chapel, without the chancel stands out with gabled bays from the north-west and also the south-west, like a tower. On the north-west the apse juts out, on the south-west a rosette ornament is found in the wallface. This ornament is designed of two circular motifs, standing above each other. The upper one, a larger stone trellised opening is held together with the lower one by a frame with mouldings in such a way that there is a smaller, unornamented bezant motif in the strip between the openings. The frame of double moulding is different from the aforementioned, as the projecting, half-round sectioned members are farther from each other, between them runs a grille-like geometric pattern. The semi-circular arched framing of the lower opening accords with the framing of the floor windows of the main front. The transition between the round lower stone grid and its semicircular framing is provided by tiny circles placed in the lower arch nooks. This complex, large-sized architectonical element together with the apse visible from the sides shows explicitly the location of the chapel in the building.

To the east the front continues with simpler forming from the chancel of the chapel, following the inner disposition of the building. The eaves are horizontal, held by a miniature gallery of smaller height than those previously. On the ground floor there are straight headed openings with a framework of semicircular mouldings. The inner arch runs around the form, the outer semicircular arch runs out at shoulder height in a horizontal direction; the lunettes are empty but of the same shade as the colour of the sections. The openings of the mezzanine like everywhere else have a form of hood-mouldings on the building, on this mezzanine they are doubled, like coupled windows, following the curve of the ground-floor openings. The first-floor openings are straight-headed, their frames are semicircular arched like the ground-floor design. The ornamentation is richer than that of the lower levels, there is grid motif in the lunettes and a geometric pattern in the window-skirt framed by floating buttresses. The self-composed part of the front is broken by a pattern slewing from the axes of the two sides of the carriage passage.

The body of the carriage passage linked the two-storey guesthouse with the castle. Its outer form follows the inner division. The inner part covered by a cross-arched vault, which was provided for the carriages to drive over, juts out from the front; its upper body is closed by a geometric plant patterned battlement, on its edges it is framed by responds, the top of which shapes a bastion-like form. The dominant element of the framed composition, which evolves in this way, is of course the circular headed gateway. This is framed by mouldings and, along the arch a narrower geometric and wider oriental ornament that reminds of ogee arched forms. The dentil pattern, which can be considered as an impost, continues on the responds. The round pattern in the arch nooks above the opening of the gateway is like the rosette of the side elevation of the chapel. Above the arch there is a banding covered by a grille-like pattern, then a cubic headed miniature gallery. The top of this gallery is ogee arched, the pattern matched with bezant motifs is like the loggia of the main face but smaller in size. The arcature supporting the pillar comprises horseshoe arches. The passage joined the buildings on both of its sides with areas of a smaller volume. The impost of the middle part and the grilled pattern above the gateway run on this neck-piece. On the ground floor of the carriage passage there are simple, straight headed doors with a round window above them, then a circular headed coupled window comes in at the height of the mezzanine of the castle. The design of the ground floor and the mezzanine also curves with the front of the castle. The design of the miniature gallery on the top of the neck-pieces is no longer visible, the rendering is missing from all four sides. However, in this way the structure of the brick wall, the system of the supporting arches and the shaped bricks are perceptible.

\subsection{South-eastern face}

The south-eastern face of the castle opening to the park is divided into three parts, like the other facades; on its left side it starts with a gabled part similar to the corner construction of the chapel, this part is linked together with the balconied tower by a wing composed of three axes, having straight eaves.

On the ground floor of the bay of the gabled left side there are two openings of the same design as the ground-floor windows of the south-western face and three hood-moulded windows. The openings of the first floor are ordered like that of the south-west, the three windows are held together by their common frame and window-skirt. Above, the spandrel below the miniature gallery is filled out by two smaller circular-headed openings and a larger one of the same type, having a common moulding frame. On two period representations there is pattern on the rendering below the gabled section 8 It follows the brick imitation of the rendering with a rhombus-shaped pattern. Presumably, it is just a product of the draughtsman's imagination as there is no trace of such a pattern at all on the site, moreover this pattern does not fit the frontal composition either.

The frontal design of the three-axis wing linking the bay of the right side with the tower is like that of the south-western face, only the ornamentation of the first-floor windows is different. Here, there are geometric patterns shaped into circles in the lunette, the framing around the arch is like the frames of the floors of the main front.

The front of the tower differs from the design of the main

\footnotetext{
${ }^{8}$ AUGUSTICH 1876. pp. 37., HORVÁTH 1998. cover
} 
front only on the ground floor, here there is a richly ornamented balcony of strong oriental impact, to which a circular-headed door leads. The edges of this balcony are supported by threethree square-headed columns. The form of the railing and the columns are the same as the elements of the loggia of the main front. Nevertheless, the mouldings starting from the capitals of the columns give the frame to a more complicated pattern. The closing of the top of the salient bulk is also similar. Above the corner columns a vertical banding emerges, laterally from the external columns a quarter-circular arch and from the front elevation a raised semicircular arch. Between the mouldings, which can be considered as construction lines, there is a splendid range of patterns consisting of oriental grills, geometric and foliated patterns. This balcony, being the most ornamented part of the castle, stands out as the jewel of the body of the tower.

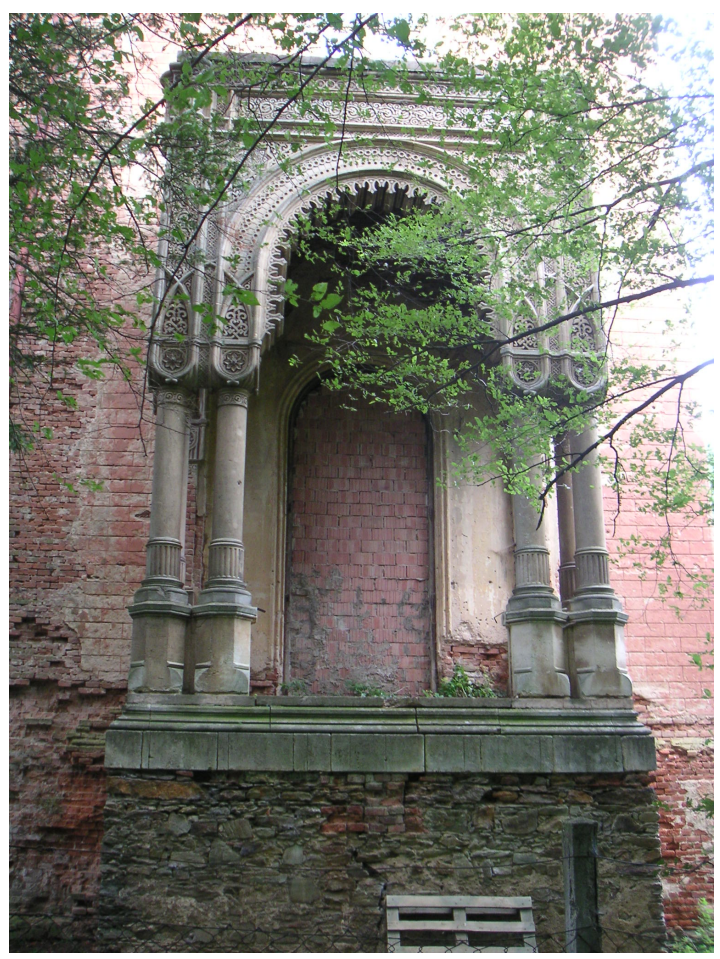

Fig. 13. Balcony of the tower

\section{The issue of the style}

The very richly formed castle may seem to be a free and unbridled game of the imagination but after careful consideration it can be stated that the ornaments are placed in a determined system on all the facades. On the sides of the building similar opening forms and framings belong to each level. The designer worked with only tiny details. For example the hoodmoulded windows appear as coupled windows or in a group of three on the mezzanine, the first-floor windows are designed as combinations of two sorts of window-skirts and three sorts of lunettes. The gables are closed everywhere by stepped miniature galleries, a richer variant of this takes shape in the loggia of the tower, a reduced variant holds the horizontal eaves. However, in case of the grilled and foliated patterns the designer really had a flight of imagination. The different faces and the diverse details are held together by the coordinated body form, the powerful fox red base colour and the uniform moulded profiling.

The writings evaluating the castle are colourful when determining the style:

"nice mansion built in Byzantine style" (1876);

"The castle was built, true to its name, of red bricks, in rich Romanesque style.” (1877);

“monumental castle built in Moorish style" (1898);

"Romantic-eclectic building” (1968);

"They included all possible stylistic marks: the Romanesque and Moorish ones appear as well as late Gothic and renaissance ones.” (1974);

“... it evokes the world of the Romanesque and the Venetian renaissance, with some Moorish impact. If it can be classified to one of the schools of style at all, (...) we can connect it to the Rundbogenstyle." (1980) 9

After taking a good look at the whole building it is not surprising that the writings evaluating the style of the castle reflect such different opinions. If, after the circumnavigated depiction, we analyse the appearance of the building in respect of the cited styles, the difference between the categorizing statements becomes understandable. When planning, Antal Wéber selected from a very large mine of the historical styles, ranging from the early Romanesque to the Rundbogenstyle, and it is just a matter of a subjective point of view, which one we accentuate. The use of square-headed columns and miniature galleries can be connected to the Romanesque. The vault below the gallery in the vestibule and the hood-moulded windows of the mezzanine evoke the Gothic, the building cannot be considered as Gothicised though. The detail forms of the outstanding parts of the castle like the loggia of the main front, the balcony of the tower, the carriage passage can be termed Oriental or Moorish. In case of the framing of the semicircular openings Antal Wéber adapted the developed forms of the Rundbogenstyle of the $19^{\text {th }}$ century.

The building is historicizing by mixing the styles from some architectural elements like the column of the carriage passage shown above to the composition itself. However, the building is basically differentiated from the style-mixing historicism of the close of the $19^{\text {th }}$ century by the fact that every architectural unit is still part of a suite with the traditional formal logic, with traditional proportions.

The concept of the whole building is given by its fortresslikeness, in this respect it can really be connected to the English Gothic, whereas the asymmetric composition of the main face evokes Venice, but the others are formed totally freely, it is hard to discover any concrete compositional archetype. It can be said that the Erdődy Castle in Vörösvár is undisputedly a romantic creation, with very individual, style-mixing historicizing form.

\footnotetext{
9 AUGUSTICH 1876. pp. 38., PULSZKY 1877. pp. 731., BOROVSZKY 1898 pp. 113., RADOS 1931. pp. 23., SCHMELLER 1968. pp. 192., SCHMELLER-KITT 1974. pp. 421., SISA 1980. pp. 105.
} 
In the forming detail of the Hungarian Romantic castles of the period we can discover a lot of affinitive features. The flat roof tower is placed often asymmetrically, for example in Nádasdladány, in Nagyhörcsökpuszta, in Petted, in Öraljaboldogfalva, the construction of corner pillars, which suggests the fortresslikeness, are emphatic in their form. For the tower of the castle in Vörösvár, however, the tower of the church in Fót may have served as an archetype, not taking the castle in Galánta into account, which was also planned by Antal Wéber. The gabled forms of the bays are also common, we can even find their stepped variant in many places, for example in Mikósdpuszta, in Zsennye, in Nádasdladány. The front with arcature, or with its variant reduced to a square form, is also common below the eaves and the gables, whereas the miniature gallery was used rather on churches. The overwhelming majority of the Romantic castles of the period take strongly the Gothicising effect, which can only be discovered in traces on the Erdődy Castle in Vörösvár and in its fortress-like conception. Besides the identifiable similarities and marks the strong effect of the oriental ornaments and the coordinated body make the castle very individual.

In the European architecture of the period, the archetype of the fortress-like palace design is the English neo-Gothic and the aristocrats of the Reform period who travelled abroad could know well this school, almost every castle of Hungarian Romanticism follows this direction in some way. The use of the oriental detail forms is principally the characteristic of the architecture of the synagogues, it is very rare in case of the burghers' or the lords' constructions. This is also a reason why this work of Wéber is worthy of special attention amongst the memories of Hungarian Romanticism.

\section{References}

1 Augustich I, Két kép Vas megyéból, Vasárnapi Újság (1876).

2 Horváth H, Régvolt magyar kastélyok, Gemini Budapest Kiadó, Budapest, 1998.

3 Loibersbeck J, Eberau und Rotenturm, Volk und Heimat (Unknown Month 1961).

4 Pulszky F, Két magyar úri lak, Fôvárosi Lapok (1877), no. 150.

5 Rados J, Magyar kastélyok, Múemlékek Országos Bizottsága, 1931.

6 Sisa J, Adatok a magyarországi romantikus kastélyépítészethez, Ars Hungarica (1980), no. 1.

7 Schmeller A, Das Burgenland, seine Kunstwerke, Historischen Lebens- und Siedlungsformen, Verlag St. Peter, Salzburg, 1968.

8 Schmeller-Kitt A, Österreichische Kunsttopographie, Anton Schroll \& Co., Wien, 1974. Band XL. Die Kunstdenkmäler des Politischen Bezirkes Oberwart.,.

9 Ulbrich K, Die Baugeschichte der Erdödy-Schlösser in Rotenturm an der Pinka, Burgenländische Heimatblätter (1978), no. 3, 97-132.

10 Ybl E, Lotz Károly élete és múvészete, Magyar Tudományos Akadémia, Budapest, 1938.

11 _ Wéber Antal, Építés és Közlekedéstudományi Közlemények (1958), 417-442.

12 Zádor A, A klasszicizmus és a romantika építészete Magyarországon, Magyar Helikon, Corvina, Budapest, 1981.
13 Borovszky S (ed.), Magyarország vármegyéi és városai. Vasvármegye, Apollo Irodalmi és Nyomdai Részvénytársaság, Budapest, 1898. 